\title{
ACCUMULATION OF TRACE METALS IN MANGROVE PLANT SONERATIA CASEORALIS IN SONGKHLA LAKE, THAILAND
}

\author{
Pradit, S. $^{{ }^{*}}$ - ShaZILI, N. A. M. ${ }^{2}-$ PATTARATUMRONG, M. S. ${ }^{1}-$ ChOTIKARN, P. $^{1}-$ \\ KobKEATTHAWIN, T. $^{1}$ - YUCHAROEN, $M .{ }^{1}{ }^{-}$TOWATANA, P. ${ }^{1}$ \\ ${ }^{1}$ Coastal Oceanography and Climate Change Research Center, Marine and Coastal Resources \\ Institution, Prince of Songkla University, Songkhla Province, Thailand \\ ${ }^{2}$ Ocean Research Institute, Univerisiti Malaysia Terengganu, Kuala Terengganu, Malaysia \\ *Corresponding author \\ e-mail: spradit22@gmail.com; phone:+66-74-282-329; fax:+66-74-212-782 \\ (Received $19^{\text {th }}$ Apr 2018; accepted $13^{\text {th }}$ Jun 2018)
}

\begin{abstract}
Mangrove sediment and mangrove plant Soneratia caseolaris in Songkhla Lake, Thailand have been increasingly threatened by trace metal pollution. Mangroves receive trace metal pollution from upstream areas and the sea. However, little is known about the mangrove plant's capacity to uptake and store trace metals. In this study, the concentrations of $\mathrm{As}, \mathrm{Cd}, \mathrm{Pb}$ and $\mathrm{Zn}$ in mangrove plant parts (leaf, root, and bark) of Sonneratia caseolaris and sediments were determined. Sediment and plant samples were digested using total metal concentration procedure and ICPMS techniques. It was found that the maximum values of total concentrations of As in mangrove sediments were classified as heavily polluted according to USEPA. The highest concentrations of $\mathrm{As}$ and $\mathrm{Zn}$ were found to be in bark whereas $\mathrm{Cd}$ and $\mathrm{Pb}$ in the root. The fractions of all the metals were measured using BCR techniques and their results revealed that the bioavailability fraction was greater than the residual fraction. The order of the amounts of trace metals present in the fractions was as follows; As: Oxidizable > Reducible > Residual > Exchangeable and the order of Cd: Exchangeable > Reducible > Oxidizable > Residual. Both BCF and TF values showed limited accumulation of these elements in their aboveground parts and thus presented a low food chain hazard except at Phawong and U-Taphao canals.
\end{abstract}

Keywords: BCR techniques, coastal lagoon, $B C F, T F$, food chain

\section{Introduction}

Mangrove forest is a group of trees and shrubs and commonly found in coastal areas. Mangrove is like a connection place between land and sea and important to the ecosystem especially to the aquatic population. Mangroves are an important food source of aquatic fauna in the tidal areas. In addition, the elongated root system makes it possible to trap sediment and trap pollutants such as trace metals. Generally, mangrove increases metal accumulation in sediments by modifying the soil acidity, redox potential, organic contents and salinity (Zhou et al., 2010; Sekomo et al., 2011) and subsequently reduces metal exposure to adjacent aquatic environment (Nath et al., 2013). Active uptake requires metabolic energy and takes place against a chemical gradient. The rate of heavy metals uptake is corresponding with its available pool at the root surface (Lanno et al., 2004). For example, when $\mathrm{As}, \mathrm{Cd}$ and $\mathrm{Pb}$ are present in soluble forms in pore water, plant roots are able to take up great amounts of these metals. The uptake rates increase as concentration in the solutions increase. The plant uptake is also affected by temperature. According to Pendias and Pendias (2001), a higher ambient temperature influences a greater uptake of trace metals by plants.

It is widely recognized that the adverse impact of heavy metals does not simply depend on their concentrations but critically on their bioavailable fraction of the total metal 
concentration in sediment (Kim et al., 2015; Tokalioglu et al., 2000). Toxicological bioavailability is defined as a bioaccumulation effect of heavy metals within plants. Among various pollutants, trace metals with persistence, non-biodegradation, toxicity and bioavailability pose a major threat to the mangrove biodiversity and human health (Liu et al., 2014). Mangroves have the capacity to contain trace metals by accumulating them in their sediments and plant tissues (MacFarlane et al., 2003). Accumulation of these metals also can cause potential problems to animals and human through food chain interaction (Hosani and Anouti, 2014).

Soneratia caseolaris is one of the mangrove trees found in Songkhla lake, Thailand and a lead or pioneer species. In the Outer Section of Songkhla Lake, Soneratia caseolaris is generally found at the mouth of the Phawong canal and U-Taphao canal and Kuannieng District, the Middle Section of Songkhla Lake is found in Kukhut non hunting areas as well. In the Songkhla Lake, there were several studies on trace metal contamination in the mangrove sediment but little is known about heavy metal uptake by mangrove plant (Sonneratia caseolaris). Therefore, the aims of this study were to determine the bioavailability of $\mathrm{As}, \mathrm{Cd}, \mathrm{Pb}$ and $\mathrm{Zn}$ in mangrove sediments of the Songkhla Lake using modified European Community Bureau of Reference (BCR) sequential extraction procedure and to analyze the accumulation of trace metals (As, $\mathrm{Cd}$, $\mathrm{Pb}$ and $\mathrm{Zn}$ ) in mangrove sediment and mangrove plant parts (leaves, root, bark) of Sonneratia caseolaris.

\section{Material and method}

\section{Study area}

The Songkhla Lake is a shallow coastal lagoon located in the southern part of Thailand and occupies approximately $1,042 \mathrm{~km}^{2}$ formed by an interaction of land and ocean processes over geological time (Sompongchaiyakul and Sirinawin, 2007). The lake is divided into 4 sections; Thale Noi, Inner Section, Middle Section and Outer Section. The salinity ranges from fresh water in Thale Noi to saline water in the Outer Section. The Outer Section is connected to the Gulf of Thailand through a deep and narrow outlet at Songkhla city. The system receives runoff and wastewater from the surrounding watershed. The runoff carries sediment onto the lakes, which will be transported through the lake by the general movement of water towards the Gulf of Thailand. According to the EmSong Project (1998), the average residence time of the water mass in the Inner, Middle and Outer Lakes is 55, 28 and 15 days respectively. The average sediment accumulation rate of in the lake is 2.5-3.5 mm/year and at some places it is higher than $15 \mathrm{~mm} /$ year (Sojisuporn, 2005). The average depth of Inner, Middle and Outer Lakes is 2, 1.5 and 1.5 meters, respectively. The lake is facing problems of environmental degradation due to urban expansion and industrialization. Sources of pollutants to the lake system include municipal wastes from Hat Yai and Songkhla cities, industrial wastes mainly related to the rubber industries, seafood processing industries, mining activities and pollution from boats in Songkhla harbour (Sompongchayakul and Sirinawin, 2007; Pradit et al., 2010).

\section{Sample collection and preparation}

The sediment cores were collected from 4 stations (Fig. 1) which were located in the Middle Section (station 1: Kukhut non hunting area) and in the Outer Section (station 2: Kuannieng, station 3: Phawong canal and station 4: U-Taphao canal). The selected station 
based on the appearance of Soneratia caseolaris was found in the Middle Section (Kukhut non hunting area; station 1) and in the Outer Section of the lake (Kuannieng, Phawong and U-Taphao canals). The survey was carried out in November, 2016.

The surface of mangrove sediment $(0-10 \mathrm{~cm})$ was taken from the active root zone using a Plexiglas tube $(5 \mathrm{~cm}$ diameter and $30 \mathrm{~cm}$ length) by pushing into the bottom sediment with 3 replicates for each station. After that the sediment cores were sectioned $5 \mathrm{~cm}$ (1 core got 2 pieces) and then packed into a plastic zip lock, labeled and put in to a plastic container before being transported to the laboratory.

Mangrove plant; Sonneratia caseolaris samples consisted of root, bark and leaf. The leaves (old leave $=$ yellow colour, mature leave $=$ green colour and young leaves) were collected by hand pick (in total about 30 leaves per stations) whereas roots (about 10 roots per station) and barks (about 5 pieces; each piece about $3 \times 5 \mathrm{~cm}$ ) were collected using a ceramic knife. The plant samples were stored in clean plastic bags. The $200 \mathrm{~g}$ wet sample (plant and sediment) of each station was put on tray and then oven dried at $50{ }^{\circ} \mathrm{C}$, homogenized and grinded in a mortar and sieved through a $1 \mathrm{~mm}$ nylon sieve and then stored in plastic zip locked bags with label and kept in desiccators prior to further analysis.

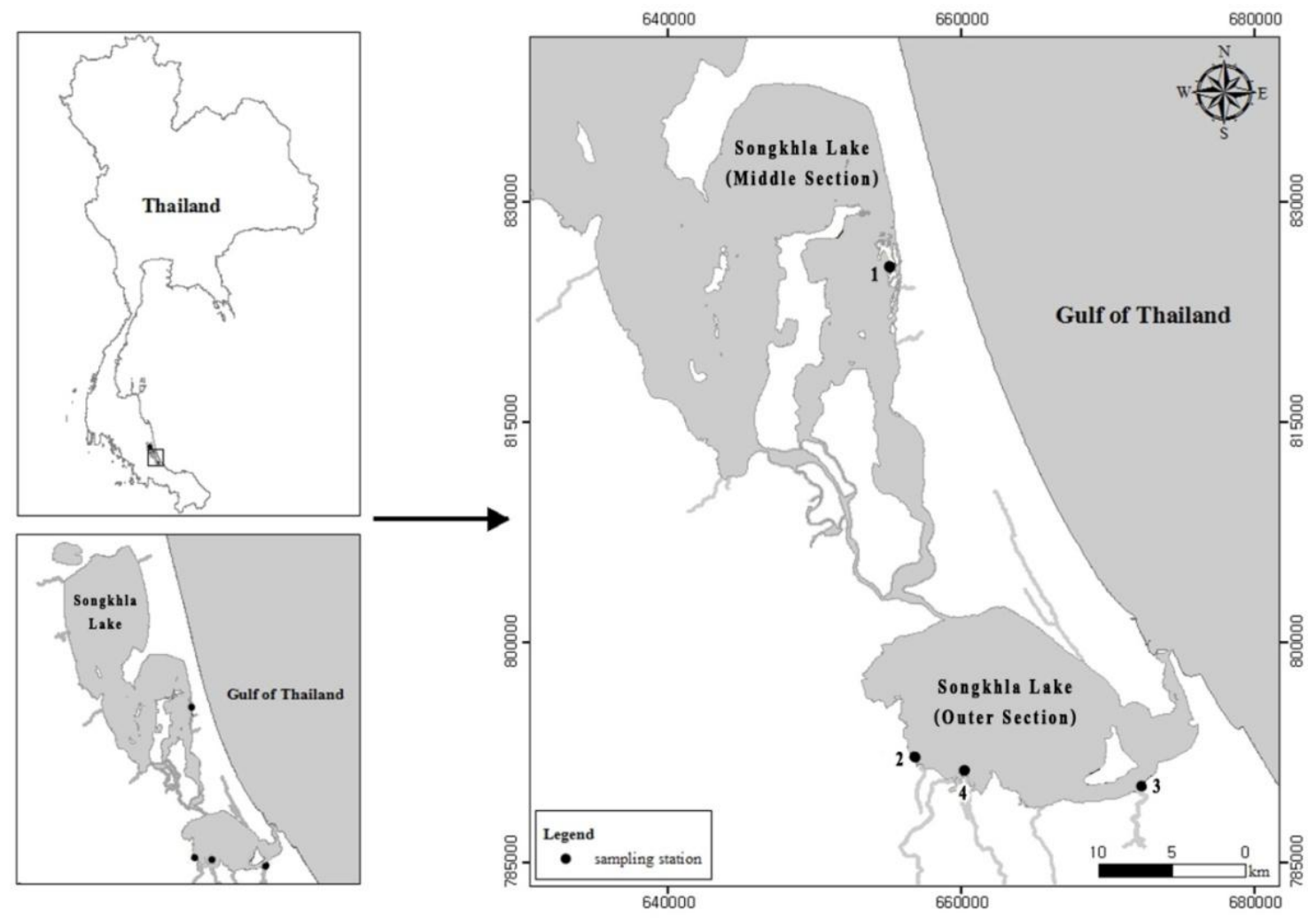

Figure 1. Map of sampling station in Songkhla Lake (station 1: Kukhut non hunting area; station 2: Kuannieng; station 3: Phawong canal; station 4: U-Taphao canal)

\section{Sample analysis}

The bulk sediment samples (about $0.1 \mathrm{~g}$ ) were totally digested in an acid mixture (5 $\mathrm{ml} \mathrm{HCl}: 8 \mathrm{ml} \mathrm{HNO}: 2 \mathrm{ml} \mathrm{HF}$ ) and analyzed for trace metals, according to the published methodologies of Noriki et al. (1980) Chojnacka et al. (2004) and Loring and Rantala (1992), with some modifications (the Teflon vessels were heated in an oven instead of a 
microwave until complete digestion of the sample occurred). The amounts of trace metals (As, $\mathrm{Cd}, \mathrm{Pb}$ and $\mathrm{Zn}$ ) were measured by ICP-MS (Perkin Elmer Elan 9000). The sediment certified reference material; SRM 1646/estuarine sediment was similarly analyzed to validate the accuracy of the analytical procedure. The analytical values were within $90 \%$ of the certified values, which demonstrated the validity of the methods applied. Plant sample was digested in a closed teflon vessel. Sample of $0.5 \mathrm{~g}$ was dissolved in $5 \mathrm{ml}$ of $\mathrm{HNO}_{3}$ (Chojnacka et al., 2004). Concentrations of $\mathrm{As}, \mathrm{Cd}, \mathrm{Pb}$ and $\mathrm{Zn}$ in digested samples were then determined by Inductively Coupled Plasma Mass Spectrometry (ICPMS). Standard reference material for plant (Peach Leaves: NIST 1547) was digested following the same procedure and analyzed for metal concentrations to validate accuracy and precision of the analysis.

Sequential extraction of mangrove sediment was performed using the revised BCR protocol (Rauret et al., 1999) briefly describes as follows:

Step 1 (Fraction 1: Exchangeable and acid soluble fractions): $40 \mathrm{ml}$ of $0.11 \mathrm{~mol} / \mathrm{l}$ acetic acid was added to $1 \mathrm{~g}$ of the air-dried sediment sample in a $50 \mathrm{ml}$ polyethylene centrifuge tube. The tube was shaken for $16 \mathrm{~h}$ at room temperature at a speed of $23 \pm 1$ $\mathrm{rpm}$. The extract was separated from the solid residue by centrifugation $3000 \mathrm{rpm}$ for $20 \mathrm{~min}$ ), decanted into a polyethylene bottle and stored at $4{ }^{\circ} \mathrm{C}$. The residue was washed by shaking with $20 \mathrm{ml}$ of distilled water for $15 \mathrm{~min}$ and centrifuging after which the supernatant was discarded.

Step 2 (Fraction 2: Reducible fraction): $40 \mathrm{ml}$ of $0.5 \mathrm{~mol} / 1$ hydroxylamine hydrochloride (adjusted to $\mathrm{pH} 1.5$ by addition of a fixed amount of $\mathrm{HNO}_{3}$ ) was added to the residue from step 1, and the extraction performed as in step 1 above.

Step 3 (Fraction 3: Oxidizable fraction): $10 \mathrm{ml}$ of $8.8 \mathrm{~mol} / \mathrm{l}$ hydrogen peroxide was added in aliquots to the residue from step 2 . The vessel was covered loosely and the contents were digested at room temperature for $1 \mathrm{~h}$ with occasional agitation. It was then placed in a water bath and digested at $85{ }^{\circ} \mathrm{C}$ until the volume was reduced to less than $3 \mathrm{ml}$. Another $10 \mathrm{ml}$ of the hydrogen peroxide was added, and further heated to near dryness. Thereafter, $50 \mathrm{ml}$ of $1.0 \mathrm{~mol} / \mathrm{l}$ ammonium acetate (adjusted to $\mathrm{pH} 2 \mathrm{with}$ $\mathrm{HNO}_{3}$ ) was added, and the extraction was performed as in the previous steps.

Step 4 (Fraction 4: Residual fraction): The residue from step 3 was transferred into a suitable vessel and the metal content was determined by microwave-assisted digestion with aqua regia. This step was for analyzing the metals content in their primary and secondary minerals.

The trace element (As, $\mathrm{Cd}$ and $\mathrm{Pb}$ ) content of each fraction was analyzed using ICPMS model Perkin Elmer Elan 9000.

\section{Data analysis and statistical}

Two comparative measures were chosen to assess the trace metals uptake and distribution within the plant. Bioconcentration factor (BCF) and translocation factor (TF) was calculated using the following equations:

$$
\begin{gathered}
\mathrm{BCF}=[\text { plant tissue }] /[\text { sediment }] \\
\mathrm{TF}=[\text { shoot }] /[\text { root }](\mathrm{TF}>1 \text { : high mobility })
\end{gathered}
$$

where [ ] is metal concentration in $\mu \mathrm{g} / \mathrm{g}$. 
In order to evaluate the degree of trace metal amount in the mangrove sediments of mangrove ecosystem, ecological risk assessment was conducted using the Håkanson, ecological risk index $\left(\mathrm{R}_{\mathrm{I}}\right)$ (Eqs. 1 and 2; Håkanson, 1980).

$$
\begin{gathered}
R_{I}=\sum E r^{i}=\sum \operatorname{Tr}^{i} C f^{i} \\
C f^{i}=C_{o}^{i} / C_{n}^{i}
\end{gathered}
$$

where:

$\mathrm{R}_{\mathrm{I}}=$ the sum of all risk factors for heavy metals in sediments

$\mathrm{Er}^{\mathrm{i}}=$ the monomial potential ecological risk factor

$\operatorname{Tr}^{\mathrm{i}}=$ the toxicity coefficient which represents the toxic response factor for a given metal. The value of $\mathrm{Tr}$ for $\mathrm{As}, \mathrm{Cd}, \mathrm{Pb}$ and $\mathrm{Zn}$ is 10, 30, 5 and 1 respectively

$\mathrm{Cf}^{\mathrm{i}}=$ the contamination factor

$\mathrm{Co}^{\mathrm{i}}=$ the concentration of metal in the sediment of mangrove ecosystem

$\mathrm{Cn}^{\mathrm{i}}=$ the background value of heavy mental in coastal sediment

\section{Statistic analysis}

The data analysis using ANOVA to detect if any significant difference in mean exited between the mangrove sediment and plant parts. Duncan's new multiple range test (DMRT) was used to describe the differences between the variables (sediment and plant parts). Significance was set at 95\% confidence level. Correlation was used to clarify the relationship between sediment fractions and metal accumulation in plant parts.

\section{Results}

\section{Sediment characteristic in mangrove sediment}

The metal concentrations in sediments from of Songkhla Lake (Table 1) ranged from 20.4 (station 1) - 50.5 (station 2) $\mu \mathrm{g} / \mathrm{g}$ dry weight for As, 0.006 (station 4) -0.182 (station 3) $\mu \mathrm{g} / \mathrm{g}$ dry weight, for $\mathrm{Cd}, 48.8$ (station 4) -78.8 (station 1) $\mu \mathrm{g} / \mathrm{g}$ dry weight, for $\mathrm{Pb}$ and 48.6 (station 4) -126.6 (station 1) $\mu \mathrm{g} / \mathrm{g}$ dry weight, for Zn. The amounts of As, $\mathrm{Zn}$ and $\mathrm{Pb}$ were highest at Kuannieng (station 2) whereas $\mathrm{Cd}$ was highest at Phawong canal (station 3). The amounts of $\mathrm{Zn}, \mathrm{Cd}$ and $\mathrm{Pb}$ were lowest at mouth of U-Taphao canal (station 4) whereas As was lowest at Kukhut (station 1). Besides that the results of the selected physical properties of sediment and water samples were summarized in Table 1. The $\mathrm{pH}$ in water ranged from $7.03-7.85$ and in sediment ranged from 6.717.53. Salinity ranged between $8 \mathrm{ppt}$ (station1) - $20 \mathrm{ppt}$ (station 2 ).

Table 1. Trace metals, physical properties of sediment and water in Songkhla Lake

\begin{tabular}{c|c|c|c|c|c|c|c|c|c}
\hline \multirow{2}{*}{ Station } & \multirow{2}{*}{ pH water } & \multirow{2}{*}{ Salinity (ppt) } & \multirow{2}{*}{ pH sed } & \multirow{2}{*}{ Eh (mV) } & As & Zn & Cd & Pb \\
\cline { 5 - 8 } & & & & \multicolumn{4}{|c|}{$\boldsymbol{\mu g} / \mathbf{g}$ dry weight (in sed.) } \\
\hline St.1 & 7.33 & 8 & 7.53 & -292 & 20.35 & 86.5 & 0.0759 & 59.8 \\
St.2 & 7.85 & 20 & 6.71 & -63 & 50.5 & 126.6 & 0.0984 & 78.8 \\
St. 3 & 7.42 & 17 & 7.4 & -149 & 28.7 & 102.1 & 0.1818 & 51.3 \\
St.4 & 7.03 & 10 & 6.99 & -79 & 31.7 & 48.6 & 0.0061 & 48.8 \\
\hline
\end{tabular}




\section{Accumulation of trace metals in Sonneratia caseolaris}

Accumulation of trace metals ( $\mathrm{As}, \mathrm{Cd}, \mathrm{Pb}$ and $\mathrm{Zn}$ ) in Sonneratia caseolaris is shown in Table 2 and summarized as below:

As: The amount of As ranged from $0.20-4.72 \mu \mathrm{g} / \mathrm{g}$ dry weight. It was found that the concentration of As was highest in the barks $(4.72 \mu \mathrm{g} / \mathrm{g}$ dry weight) at U-Taphao Canal (station 4), followed by roots $(1.51 \mu \mathrm{g} / \mathrm{g}$ dry weight) and old leaves $(1.03 \mu \mathrm{g} / \mathrm{g}$ dry weight).

$\mathrm{Cd}$ : The amount of Cd ranged from $0.003-0.041 \mu \mathrm{g} / \mathrm{g}$ dry weight. The result revealed that the concentration of Cd was highest in root $(0.041 \mu \mathrm{g} / \mathrm{g}$ dry wt. $)$ at Phawong canal (station 3), followed by old leaves $(0.033 \mu \mathrm{g} / \mathrm{g}$ dry weight), green leaves $(0.029 \mu \mathrm{g} / \mathrm{g}$ dry weight) and barks $(0.029 \mu \mathrm{g} / \mathrm{g}$ dry weight $)$.

$\mathrm{Pb}$ : The amount of $\mathrm{Pb}$ ranged from $0.18-6.76 \mu \mathrm{g} / \mathrm{g}$ dry weight. It was found that the concentration of $\mathrm{Pb}$ was highest in the root $(6.76 \mu \mathrm{g} / \mathrm{g}$ dry wt.) at U-Taphao canal (station 4), followed by bark (4.12 $\mu \mathrm{g} / \mathrm{g}$ dry weight) and old leaves $(2.74 \mu \mathrm{g} / \mathrm{g}$ dry weight).

$\mathrm{Zn}$ : The amount of $\mathrm{Zn}$ ranged from 2.66-35.80 $\mu \mathrm{g} / \mathrm{g}$ dry weight. The result showed that concentration of $\mathrm{Zn}$ was highest in the bark $(35.80 \mu \mathrm{g} / \mathrm{g}$ dry wt.) at Kuannieng (station 2), followed by young leaves $(17.10 \mu \mathrm{g} / \mathrm{g}$ dry weight) and root $(16.58 \mu \mathrm{g} / \mathrm{g}$ dry weight).

Overall the amounts of trace metals were in order $\mathrm{Zn}>\mathrm{Pb}>\mathrm{As}>\mathrm{Cd}$.

Table 2. Trace metals content in different parts of Sonneratia caseolaris of Songkhla Lake

\begin{tabular}{c|c|c|c|c|c|c}
\hline \multirow{2}{*}{ Station } & \multirow{2}{*}{ Plant part } & $\mathbf{Z n}$ & \multicolumn{3}{|c|}{ As } & \multicolumn{2}{|c|}{$\mathbf{C d}$} & $\mathbf{P b}$ \\
\cline { 3 - 6 } & & \multicolumn{4}{|c}{$\mathbf{\mu g} / \mathbf{g}$ dry weight) } \\
\hline 1 & Root & 16.16 & 0.83 & 0.021 & 1.39 \\
1 & Bark & 9.90 & 0.20 & 0.029 & 0.94 \\
1 & Leaf_Y & 17.10 & 0.26 & 0.009 & 0.28 \\
1 & Leaf_M & 12.98 & 0.29 & 0.014 & 0.48 \\
1 & Leaf_O & 12.08 & 0.70 & 0.022 & 0.73 \\
2 & Root & 24.40 & 1.51 & 0.027 & 1.85 \\
2 & Bark & 35.80 & 0.79 & 0.026 & 2.08 \\
2 & Leaf_Y & 4.14 & 0.04 & 0.006 & 0.18 \\
2 & Leaf_M & 11.10 & 0.36 & 0.029 & 1.12 \\
2 & Leaf_O & 10.44 & 0.57 & 0.033 & 2.74 \\
3 & Root & 16.58 & 0.89 & 0.041 & 2.12 \\
3 & Bark & 2.66 & 0.28 & 0.010 & 0.43 \\
3 & Leaf_Y & 11.20 & 0.26 & 0.004 & 0.27 \\
3 & Leaf_M & 5.36 & 0.53 & 0.006 & 0.44 \\
3 & Leaf_O & 2.84 & 0.95 & 0.007 & 0.32 \\
4 & Root & 5.88 & 0.41 & 0.003 & 6.76 \\
4 & Bark & 8.04 & 4.72 & 0.019 & 4.12 \\
4 & Leaf_Y & 7.60 & 0.37 & 0.004 & 0.21 \\
4 & Leaf_M & 4.80 & 0.72 & 0.005 & 0.26 \\
4 & Leaf_O & 4.76 & 1.03 & 0.006 & 0.70 \\
\hline
\end{tabular}

Remarks: $\mathrm{Y}=$ young leave, $\mathrm{M}=$ mature leave (green colour), $\mathrm{O}=$ old leave (yellow colour) 


\section{Trace metal speciation in mangrove sediment}

The speciation of $\mathrm{As}, \mathrm{Cd}$ and $\mathrm{Pb}$ in the mangrove sediment samples from the Songkhla Lake using the BCR protocol were presented in Figure 2.
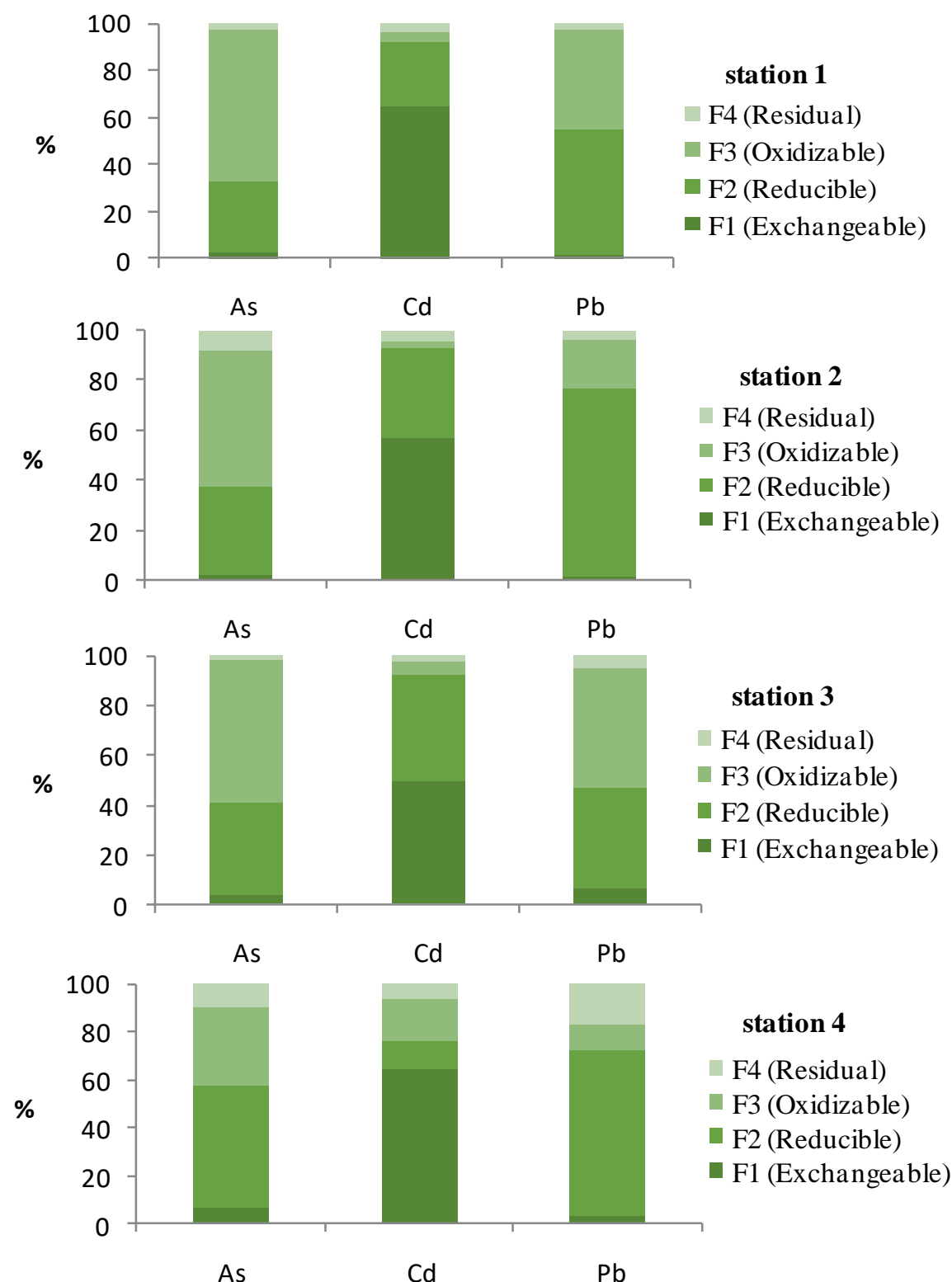

Figure 2. The speciation distribution of $A s, C d$ and $P b$ in mangrove sediments in Songkhla Lake, Southern Thailand

The results of the sequential extraction for overall stations were as follows:

Exchangeable and acid soluble fraction (F1): Cd (49.58\% - 64.33\%) was found dominant in the acid-soluble fraction (F1), associated with exchangeable cations and carbonates for all the stations.

Reducible Fraction (F2): $\mathrm{Pb}(40.89 \%-74.81 \%)$ was found dominant in $\mathrm{F} 2$ in all the stations except station 3 .This fraction is readily available with medium mobility and may be released into the environment under unstable anoxic conditions. 
Oxidizable fraction (F3): As $(32.47 \%$ - 64.76\%) was found dominant in F3 at all the stations except station 4 .Metals bound to organic matter are reasonable stable in nature however under strong oxidizing conditions such as currents, dredging, flooding and tides the organic matter can be degraded, hence leading to a release of heavy metals bound to this component (Sarkar et al., 2014; MacFarlane and Burchett, 2000).

Residual fraction (F4): $\mathrm{Pb}(2.60 \%$ - 16.49\%) was found highest in F4. The residual solid normally consists of mainly primary and secondary minerals that retained heavy metals within their crystal structure. They are regarded as immobile and unavailable fraction.

As: Oxidizable $(\mathrm{F} 3)>$ Reducible $(\mathrm{F} 2)>$ Residual $(\mathrm{F} 4)>$ Exchangeable $(\mathrm{F} 1)$

$\mathrm{Cd}$ :Exchangeable $(\mathrm{F} 1)>$ Reducible $(\mathrm{F} 2)>$ Oxidizable $(\mathrm{F} 3)>$ Residual $(\mathrm{F} 4)$

$\mathrm{Pb}$ : Reducible $(\mathrm{F} 2)>$ Oxidizable $(\mathrm{F} 3)>$ Residual $(\mathrm{F} 4)>$ Exchangeable $(\mathrm{F} 1)$

\section{Bioaccumulation factors (BAF) and transfer factors $(T F)$}

The bioconcentration factor (BCF) of Sonneratia caseolaris in different plant parts was varied as $\mathrm{As}>\mathrm{Cd}>\mathrm{Zn}>\mathrm{Pb}$. The $\mathrm{BAF}$ of $\mathrm{Zn}$, As, $\mathrm{Cd}$ and $\mathrm{Pb}$ was shown in Table 3. The bioconcentration factor $(\mathrm{BCF})$ was always below 1 for all the trace metals and all the stations except As (1.06) in old leave at Phawong canal (station 3) and Cd in old leave (1.02) at the U-Taphao canal (station 4). These results suggested that Sonneratia caseolaris showed the limited uptake of $\mathrm{Zn}$ and $\mathrm{Pb}(\mathrm{BCF}<1)$ but surprisingly not for As and Cd which BCF > 1 in old leave was found in Phawongcanal (station 3) and UTaphao canal (station 4).

Table 3. Bioconcentration factor (BCF) of $\mathrm{Zn}, \mathrm{As}, \mathrm{Cd}$ and $\mathrm{Pb}$ in Sonneratia caseolaris of Songkhla Lake

\begin{tabular}{c|c|c|c|c|c}
\hline Station & Plant part & Zn & As & Cd & Pb \\
\hline 1 & Root & 0.19 & 0.04 & 0.27 & 0.02 \\
1 & Bark & 0.11 & 0.01 & 0.38 & 0.02 \\
1 & Leaf_Y & 0.20 & 0.01 & 0.11 & 0.00 \\
1 & Leaf_M & 0.15 & 0.01 & 0.19 & 0.01 \\
1 & Leaf_O & 0.14 & 0.03 & 0.28 & 0.01 \\
2 & Root & 0.19 & 0.03 & 0.27 & 0.02 \\
2 & Bark & 0.28 & 0.02 & 0.26 & 0.03 \\
2 & Leaf_Y & 0.03 & 0.00 & 0.06 & 0.00 \\
2 & Leaf_M & 0.09 & 0.01 & 0.29 & 0.01 \\
2 & Leaf_O & 0.08 & 0.01 & 0.34 & 0.03 \\
3 & Root & 0.16 & 0.03 & 0.23 & 0.04 \\
3 & Bark & 0.03 & 0.01 & 0.06 & 0.01 \\
3 & Leaf_Y & 0.11 & 0.01 & 0.02 & 0.01 \\
3 & Leaf_M & 0.05 & 0.02 & 0.03 & 0.01 \\
3 & Leaf_O & 0.17 & 1.06 & 0.16 & 0.15 \\
4 & Root & 0.12 & 0.01 & 0.42 & 0.14 \\
4 & Bark & 0.17 & 0.01 & 3.19 & 0.08 \\
4 & Leaf_Y & 0.16 & 0.01 & 0.70 & 0.00 \\
4 & Leaf_M & 0.10 & 0.02 & 0.74 & 0.01 \\
4 & Leaf_O & 0.10 & 0.03 & 1.02 & 0.01 \\
\hline
\end{tabular}

$\mathrm{Y}=$ young leave, $\mathrm{M}=$ mature leave (green colour), $\mathrm{O}=$ old leave (yellow colour) 
The translocation factor (TF) of Sonneratia caseolaris in different plant parts varied as $\mathrm{Cd}>\mathrm{As}>\mathrm{Zn}>\mathrm{Pb}$ (Table 4). The $\mathrm{TF}$ value of $\mathrm{Zn}$ ranged $0.16-1.47 \mu \mathrm{g} / \mathrm{g}$ dry weight; As ranged 0.02-2.55 $\mu \mathrm{g} / \mathrm{g}$ dry weight; $\mathrm{Cd}$ ranged $0.10-7.60 \mu \mathrm{g} / \mathrm{g}$ dry weight; $\mathrm{Pb}$ ranged $0.03-1.48 \mu \mathrm{g} / \mathrm{g}$ dry weight. The TF of these metals was above 1 at some stations and below 1 at other stations. At U-Taphao canal (station 4) TF value was above 1 for $\mathrm{Zn}$, As, and $\mathrm{Cd}$. TF value of As and $\mathrm{Cd}$ in old leave was greater than one at station 4 and 1. $\mathrm{TF}$ value of $\mathrm{Pb}$ in old leave was greater than one at station 2 . TF value in bark was greater than 1 for $\mathrm{Zn}$ at station 1 and 4; As at station 4; $\mathrm{Cd}$ at station 1 and 4; $\mathrm{Pb}$ at station 2. Thus the result revealed that this plant species was effectively transferring $\mathrm{Cd}$ to the aerial parts. The TF of $\mathrm{Pb}$ was always below 1 (except station 2 in bark and station 3 in old leave), which might be described as having moderate mobility for this metal.

Table 4. Translocation factor (TF) for mangrove plant parts

\begin{tabular}{c|c|c|c|c|c}
\hline Station & Plant part & Zn & As & Cd & Pb \\
\hline 1 & Bark & 0.61 & 0.24 & 1.39 & 0.68 \\
1 & Leaf_Y & 1.06 & 0.31 & 0.42 & 0.20 \\
1 & Leaf_M & 0.80 & 0.35 & 0.70 & 0.35 \\
1 & Leaf_O & 0.75 & 0.85 & 1.05 & 0.53 \\
2 & Bark & 1.47 & 0.52 & 0.96 & 1.12 \\
2 & Leaf_Y & 0.17 & 0.02 & 0.22 & 0.10 \\
2 & Leaf_M & 0.45 & 0.24 & 1.08 & 0.60 \\
2 & Leaf_O & 0.43 & 0.37 & 1.23 & 1.48 \\
3 & Bark & 0.16 & 0.31 & 0.24 & 0.20 \\
3 & Leaf_Y & 0.68 & 0.29 & 0.10 & 0.13 \\
3 & Leaf_M & 0.32 & 0.60 & 0.14 & 0.21 \\
3 & Leaf_O & 0.17 & 1.06 & 0.16 & 0.15 \\
4 & Bark & 1.37 & 1.16 & 7.60 & 0.61 \\
4 & Leaf_Y & 1.29 & 0.90 & 1.67 & 0.03 \\
4 & Leaf_M & 0.82 & 1.78 & 1.76 & 0.04 \\
4 & Leaf_O & 0.81 & 2.55 & 2.42 & 0.10 \\
\hline
\end{tabular}

$\mathrm{Y}=$ young leave, $\mathrm{M}=$ mature leave (green colour), $\mathrm{O}=$ old leave (yellow colour)

\section{Ecological risk index of heavy metals in mangrove sediments of different areas}

The potential ecological risk index of single element $\mathrm{E}_{\mathrm{r}}^{\mathrm{i}}$ shown in Table 5 indicated that $\mathrm{As}$ and $\mathrm{Zn}$ were classified as moderate level whereas $\mathrm{Cd}$ and $\mathrm{Pb}$ were classified as low level. As shown in Table 5, the ecological risk indexes $\left(\mathrm{R}_{\mathrm{I}}\right)$ of trace metals in the mangrove sediments from different part of Songkhla Lake showed that Kuannieng (station 2) and Phawong canal (station 3) were classified as moderate level whereas Kukhut nonhunting area (station 1) and U-Taphao canal (station 4) were classified as low level.

\section{Comparison of trace metal concentration with Sediment Quality Guidelines (SQGs)}

Several sediment quality guidelines (SQGs) for the assessment of sediment quality using chemical and biological effect databases have been established. These SQGs are 
summarized in Table 6. NOAA presents ERL (effects range low) and ERM (effects range mean) guidelines for estuarine and marine environments which represent the $10^{\text {th }}$ and $50^{\text {th }}$ percentiles of adverse biological effects (NOAA, 1999). The MacDonald et al. (2000) SQGs for freshwater environments have a lower TEC (threshold effects concentration) and an upper PEC (probable effect concentration) at which toxicity to bottom dwelling organisms are predicted to be unlikely and probable, respectively. The US-EPA has also made classifications (non-polluted, moderately polluted, heavily polluted based on toxicity tests (Baudo et al., 1990; Filgueiras et al., 2004). Regional background values assessed from core sediment samples were reported by Choi et al. (2008) and offshore sediments in the Gulf of Thailand by Shazili et al. (1999). Background levels varied from 55-115 $\mu \mathrm{g} / \mathrm{g}$ dry weitht for $\mathrm{Zn}$, from 5-9 $\mu \mathrm{g} / \mathrm{g}$ dry weight for As, from $0.03-0.2 \mu \mathrm{g} / \mathrm{g}$ dry weight for $\mathrm{Cd}$, from $15-30 \mu \mathrm{g} / \mathrm{g}$ dry weight for $\mathrm{Pb}$.

Table 5. Ecological risk index of trace metals in mangrove sediments of Songkhla Lake

\begin{tabular}{|c|c|c|c|c|c|}
\hline $\mathrm{E}_{\mathrm{r}}^{\mathrm{i}}$ & \multicolumn{2}{|c|}{$\begin{array}{l}\text { Potential ecological risk for } \\
\text { single regulator }\end{array}$} & $\mathrm{R}_{\mathrm{I}}$ & \multicolumn{2}{|c|}{ Ecological risk for all factors } \\
\hline$<40$ & \multicolumn{2}{|c|}{ Low } & $\mathrm{R}_{\mathrm{I}}<95$ & \multicolumn{2}{|c|}{ Low (L) } \\
\hline $40 \leq \mathrm{E}_{\mathrm{r}}^{\mathrm{i}} \leq 80$ & \multicolumn{2}{|c|}{ Moderate } & $95 \leq \mathrm{R}_{\mathrm{I}} \leq 190$ & \multicolumn{2}{|c|}{ Moderate (M) } \\
\hline $80 \leq \mathrm{E}_{\mathrm{r}}^{\mathrm{i}} \leq 160$ & \multicolumn{2}{|c|}{ Considerable } & $190 \leq \mathrm{R}_{\mathrm{I}}<380$ & \multicolumn{2}{|c|}{ Considerable (C) } \\
\hline $160 \leq \mathrm{E}_{\mathrm{r}}^{\tilde{\mathrm{i}}} \leq 320$ & \multirow{2}{*}{\multicolumn{2}{|c|}{$\begin{array}{l}\text { High } \\
\text { Very high }\end{array}$}} & $\mathrm{R}_{\mathrm{I}} \leq 380$ & \multicolumn{2}{|c|}{ Very high (V) } \\
\hline $\mathrm{E}_{\mathrm{r}}^{\mathrm{i}} \geq 320$ & & & & & \multirow{3}{*}{$\mathrm{R}_{\mathrm{I}}$} \\
\hline \multirow{2}{*}{ Sites } & \multicolumn{2}{|c|}{$\mathrm{E}_{\mathrm{r}}^{\mathrm{i}}$} & & & \\
\hline & $\mathrm{Zn}$ & As & $\mathrm{Cd}$ & $\mathrm{Pb}$ & \\
\hline 1 Kukhut & 44.0 & 29.1 & 3.2 & 2.7 & $78.9(\mathrm{~L})$ \\
\hline 2 Kuannieng & 64.4 & 72.1 & 4.1 & 3.5 & $144.1(\mathrm{M})$ \\
\hline 3 Phawong canal & 51.9 & 41.0 & 7.6 & 2.3 & $102.8(\mathrm{M})$ \\
\hline 4 U-Taphaocanal & 24.7 & 45.3 & 0.3 & 2.2 & $72.4(\mathrm{~L})$ \\
\hline
\end{tabular}

Table 6. Comparison the metal concentration ( $\mu \mathrm{g} / \mathrm{g} d r y$ weight) and the Sediment Quality Guidelines (SQGs)

\begin{tabular}{|c|c|c|c|c|c|c|c|c|}
\hline \multirow{2}{*}{ Element } & \multicolumn{3}{|c|}{ US EPA } & \multicolumn{2}{|c|}{ NOAA } & \multicolumn{2}{|c|}{$\begin{array}{c}\text { MacDonald et. } \\
\text { al. (2000) }\end{array}$} & \multirow{2}{*}{ This study } \\
\hline & $\begin{array}{c}\text { Non } \\
\text { polluted }\end{array}$ & $\begin{array}{c}\text { Moderately } \\
\text { polluted }\end{array}$ & $\begin{array}{l}\text { Heavily } \\
\text { polluted }\end{array}$ & ERL & ERM & TEC & PEC & \\
\hline $\mathrm{Pb}$ & $<40$ & $40-60$ & $>60$ & 46.7 & 218 & 36 & 130 & $48.8-78.8$ \\
\hline As & $<3$ & $3-8$ & $>8$ & 8.2 & 70 & 9.8 & 33 & $20.35-50.5$ \\
\hline $\mathrm{Cd}$ & & & $>6$ & 1.2 & 9.6 & 0.99 & 5 & $0.0061-0.1818$ \\
\hline $\mathrm{Zn}$ & $<90$ & $90-200$ & $>200$ & 150 & 410 & 120 & 460 & 48.6-126.6 \\
\hline
\end{tabular}

TEC: threshold effect concentration, PEC: probable effect concentration, ERL: effects range low, ERM: effects range mean

Sediment quality guidelines (SQGs) were recognized as appropriate thresholds to reveal adverse effects of heavy metals in sediments for plants, animals and human health. SQGs were applied to our study to determine the overall pollution status in sediments of Songkhla Lake. The amount of $\mathrm{As}$ and $\mathrm{Pb}$ was above the background value. Our study showed that highest amount of As at Kuannieng (station 2) of 
Songkhla Lake exceeded the ERL value; TEC value was classified as heavily polluted probably affected the health of plants and organisms. Pb levels from both sites exceeded the ERL and TEC value and were regarded as heavily polluted at Kuannieng (station 2) and classified as moderately polluted for stations 1, 3, and 4. Cd level was classified as lower than ERL and TEC. Zn was classified as moderately polluted and exceeded TEC value.

\section{The comparison of trace metals in mangrove sediment and plant parts}

Our result revealed that the total concentration of all metals (As, $\mathrm{Zn}, \mathrm{Pb}, \mathrm{Cd}$ ) in mangrove sediment no statiscally significant difference among the stations $(\mathrm{p}>0.05)$. For the comparison of the trace metal concentrations between plant parts of Soneratia caseolaris, all the values show variations among the stations. The post hoc Duncan-Test showed no significantly different accumulation in barks $(\mathrm{p}>0.05)$ whereas roots and leaves were significantly different $(\mathrm{p}<0.05)$. The comparison of the metal contamination in the different sediment fractions revealed the low metal concentration in residual fraction and high in bioavailability fractions. The post hoc Duncan-Test showed among the stations showed no significant difference in residual fraction $(p>0.05)$ whereas the other fractions (Exchangeable, Reducible and Oxidizble) were significantly different $(\mathrm{p}<0.05)$.

\section{Correlation between fractionation of heavy metals in sediment and accumulation in plant parts}

The accumulation in various parts of Soneratia caseoralis was investigated to determine the relationship between the fractionation and plant's uptake as showed in Table 7. Fraction 1 (Exchangeable) was significantly negative correlated with accumulation in leaves (young, green, old). The result indicated that Fraction 2 (Reducible) was showed positive correlation with root $(\mathrm{r}=0.634, \mathrm{p}<0.05)$, bark $(\mathrm{r}=0.682, \mathrm{p}<0.05)$ leaves $(\mathrm{Y}: \mathrm{r}=0.678, \mathrm{p}<0.05 ; \mathrm{O}: \mathrm{r}=0.712, \mathrm{p}<0.05)$. Higher Fraction 2 resulted in higher plant uptake. Fraction 3 (oxidizable) had moderate correlation $(\mathrm{r}=0.585, \mathrm{p}<0.05)$ and Fraction 4 (Residual) had high correlation with plant uptake in root $(\mathrm{r}=0.749, \mathrm{p}<0.05)$ and bark $(\mathrm{r}=0.776, \mathrm{p}<0.05)$. High correlation was found between young leave and green leave $(r=0.661, p<0.05)$ and between green leave and old leave $(r=0.933, p<0.05)$.

Table 7. Correlation between fractionation of trace metals in sediment and accumulation in plant parts

\begin{tabular}{c|c|c|c|c|c|c|c|c|c}
\hline & Fraction1 & Fraction2 & Fraction3 & Fraction4 & Root & Bark & Leaf_Y & Leaf_M & Leaf_O \\
\hline Fraction1 & 1 & & & & & & & & \\
Fraction2 & $-.590^{\prime}$ & & & & & & & & \\
Fraction3 & $-.711^{\prime \prime}$ & -.131 & & & & & & & \\
Fraction4 & -.228 & .388 & -.208 & & & & & & \\
Root & -.515 & $.634^{\prime}$ & -.005 & $.749 "$ & & & & & \\
Bark & -.480 & $.682^{\prime}$ & -.089 & $.776^{\prime \prime}$ & .573 & & & & \\
Leaf_Y & $-.798^{\prime \prime}$ & .458 & $.585^{\prime}$ & .143 & .313 & .556 & & & \\
Leaf_M & $-.742^{\prime \prime}$ & $.678^{\prime}$ & .368 & .031 & .197 & .506 & $.661^{\prime}$ & & \\
Leaf_O & $-.627^{\prime}$ & $.712^{\prime \prime}$ & .201 & .037 & .249 & .454 & .470 & $.933 "$ & 1 \\
\hline
\end{tabular}

$\mathrm{Y}=$ young leave, $\mathrm{M}=$ mature leave (green colour), $\mathrm{O}=$ old leave (yellow colour)

'Correlation is significant at the 0.05 level. "Correlation is significant at the 0.01 level 


\section{Discussion}

In this study, the samples were collected during the heavy rainy season and therefore several large freshwater bodies flowed into the lake and lessened the salinity of the lake water. However, the metal concentrations in the collected mangrove sediment samples in our study area as compared to the sediment quality guideline revealed that the As concentration was still higher than that of the quality guideline by 2-4 times and classified as heavily polluted. Comparison of our data regarding the metal concentrations ( $\mathrm{As}, \mathrm{Cd}, \mathrm{Pb}$ and $\mathrm{Zn}$ ) with the previous data from the other studies of Songkhla lake as well as other areas in the world was illustrated in Table 8. The maximum values of $\mathrm{As}$ and $\mathrm{Pb}$ at the Outer Section of Songkhla Lake previously reported by Pradit et al. (2010, 2013) were considerably lower than those of this study. Especially, As levels in Songkhla Lake were much higher than those found in Pattani bay (Pradit et al., 2016), Seitu Wetland (Pradit et al., 2016), Sundarban Wetland (Chowdhury et al., 2015) and at Kelantan Delta reported by Baruddin (2017). This result is certainly supported by Sompongchaiyakul and Sirinawin (2007), Pradit et al. (2010, 2013); who reported that concentrations of $\mathrm{As}$, and $\mathrm{Pb}$ were ascending owing to rapid urban and industrial expansion. Outer Section of Songkhla Lake receives municipal wastes from two large and rapidly expanding cities of Songkhla and Hatyai as well as agricultural and industrial discharges transported by U-Taphao canal (Sompongchaiyakul and Sirinawin, 2007). The mean concentration values of $\mathrm{As}$ and $\mathrm{Pb}$ of this study were similar to the result of Pradit et al. (2010) but higher than those of Pradit et al. (2013). It is well accepted that the mangrove area is considered as a sink of trace metals and therefore the mangrove sediment samples of this study possesses the higher amounts of trace metals than those of the lake sediment reported by Pradit et al. (2013). Although the total concentration of metal is an appropriate indicator of contamination assessment, it does not provide enough information about bioavailability and toxicity of heavy metals (Zhong et al., 2011).

Chemical fractionation differentiates metals of natural origin from those derived from anthropogenic sources. The bioavailability fractions (exchangeable, oxidizable and reducible) of $\mathrm{As}, \mathrm{Cd}$ and $\mathrm{Pb}$ in mangrove sediments of this study were greater than $90 \%$ whereas the residual fraction of these elements was very low. Thus, it was probably concluded that mangrove area in this study had high bioavailability. This may suggest that there was considerable anthropogenic input to the Songkhla Lake as compared to the low bioavailability of As (about 30\%) reported by Baruddin et al. (2017). This was probably caused by different mangrove plant types. Our sampling area was $S$. caseolaris habitat whereas Baruddin et al. (2017) was $R$. mucronata.

In our study $\mathrm{Pb}$ seemedto be accumulated in plant parts. This was concordant with the study of Toledo-Bruno et al. (2016) in Mangrove forest reserve in Mindanao, Philippines discovering of Sonneratia alba being $\mathrm{Pb}$-hyperaccumulator. Our study $\mathrm{Pb}$ was highest in root and well agreed with the study of Nazli and Hashim (2010).

Plants may be passive receptors of heavy metals, but they also exert control over uptake or rejection of some elements by appropriate physiological reactions. To illustrate this point, based on Table 3, the BAF values for all the studied heavy metals were always less than 1, which indicated that Soneratia caseolaris exhibited restricted metal sediment-root uptake for non-essential heavy metals similar to BAF of $R$. mucronata in the Outer Section of Songkhla Lake (Barrudin et al., 2017) 
Table 8. Trace metals concentrations ( $\mu \mathrm{g} / \mathrm{g}$ dry wt) in sediments of Songkhla Lake and at other sites

\begin{tabular}{c|c|c|c|c|c}
\hline & As & Cd & Pb & Zn & References \\
\hline Songkhla lake & $20.4-50.5$ & $0.006-0.182$ & $48.8-78.8$ & $48.6-126.6$ & This study \\
\hline Songkhla Lake & $5.1-25.7$ & - & - & & $\begin{array}{c}\text { Sompongchaiyakul and } \\
\text { Sirinawin, 2007 }\end{array}$ \\
\hline Songkhla Lake & $0.8-70.7$ & $0.1-2.4$ & $8.2-131$ & $5.4-561.6$ & Pradit et al., 2010 \\
\hline Songkhla Lake & $20-22.0$ & $0.21-0.28$ & $31-35$ & & Pradit et al., 2013 \\
\hline Songkhla Lake & 20.7 & & 55 & & Baruddin et al., 2017 \\
\hline Futian, China & 152.4 & & 70.7 & & Li et al., 2016 \\
\hline Pattani Bay, Thailand & $2.98-9.34$ & $0.00-0.02$ & $2.40-11.48$ & $0.01-7.06$ & Pradit et al., 2016 \\
\hline $\begin{array}{c}\text { Seitu Wetland, } \\
\text { Malaysia }\end{array}$ & $0.89-3.52$ & 0 & $0.63-1.56$ & $0.50-2.30$ & Pradit et al., 2016 \\
\hline $\begin{array}{c}\text { Kelantan Delta, } \\
\text { Malaysia }\end{array}$ & $18.28-34.95$ & & $31.30-75.84$ & & Baruddin et al., 2017 \\
\hline $\begin{array}{c}\text { Sundarban Wetland, } \\
\text { India }\end{array}$ & $3.22-4.41$ & $0.19-0.22$ & $11.6-20$ & $32.51-36.33$ & Chowdhury et al., 2015 \\
\hline Background value & 7 & 0.12 & 22.5 & 56 & Choi et al., 2008 \\
\hline Heavily polluted & $>8$ & $>6$ & $>60$ & $>200$ & US EPA \\
\hline Moderately polluted & $3-8$ & & $<3$ & $90-200$ & US EPA \\
\hline
\end{tabular}

\section{Conclusion}

The anthropogenic inputs of $\mathrm{As}$ and $\mathrm{Pb}$ were high in the mangrove sediments of the lake especially at Kuannieng (station 2). As and $\mathrm{Zn}$ were found highest concentration in bark whereas $\mathrm{Cd}$ and $\mathrm{Pb}$ were found highest concentration in root. The $\mathrm{BCF}$ and $\mathrm{TF}$ values proposed that Sonneratia caseolaris showed limited $(\mathrm{BCF}<1$, and $\mathrm{TF}>1)$ accumulation of $\mathrm{As}, \mathrm{Cd}, \mathrm{Pb}$ and $\mathrm{Zn}$ in their aboveground parts and thus presented a low food chain hazard except As and $\mathrm{Cd}$ at Phawong canal (station 3) and U-Taphao canal (station 4). The potential ecological risk index of single element indicated that As was classified as moderate risk level. The concentration of As should be concerned and regularly monitored.

Acknowledgements. This work was financially supported by the Prince of Songkla University under contract number COR590528S.

\section{REFERENCES}

[1] Baruddin, N. A., Shazili, N. A. M., Pradit, S. (2017): Sequential extraction analysis of heavy metals in relation to bioaccumulation in mangrove, Rizophoramucronata from Kelantan Delta, Malaysia. Aquaculture, Aquarium, Conservation \& Legislation. International Journal of the Bioflux Society 10: 172-181.

[2] Baudo, R., Muntau, H. (1990): Lesser known in-place pollutants and diffuse source problems. - In: Baudo, R. Giesy, J. P., Muntau, H. (ed.) Sediment Chemistry and Toxicity of In-Place Pollutants, USA.

[3] Choi, K. Y., Kim, S. H., Chon, H. T. (2008): Distributions and accumulations of heavy metals in the sediments of harbors and coastal areas in Korea. - Proceedings of the 
international symposia on geoscience resources and environments of Asian Terranes (GREAT 2008), $4^{\text {th }}$ IGCP 516, and $5^{\text {th }}$ APSEG. November 24-28, 2008. Bangkok, Thailand.

[4] Chojnacka, K., Chojnacki, A., Gorecka, H., Gorecki, H. (2004): Bioavailability of heavy metals from polluted soils to plants. - Science of the Total Environment 337: 175-182.

[5] Chowdhury, R., Favas, P. J., Pratas, J., Jonathan, M. P., Ganesh, P. S., Sarkar, S. K. (2015): Accumulation of trace metals by mangrove plants in Indian Sundarban Wetland: prospects for phytoremediation. - International Journal of Phytoremediation 17: 885-894.

[6] Emsong Project (1998): Environmental diagnosis for the Songkhla lake basin: Technical Background Report No. 9. - VKI in association with: DHI, PEM consult A/S, COWI A/S, Prince of Songkla University and Seatec International Ltd.

[7] Filgueiras, A. V., Lavilla, I., Bendicho, C. (2004): Evaluation of distribution, mobility and binding behaviour of heavy metals in surficial sediments of Louro River (Galicia, Spain) using chemometric analysis: a case study. - Science of the Total Environment 330: 115-129.

[8] Håkanson, L. (1980): An ecological risk index for aquatic pollution control of sedimentEcological approach. - Water Research 14: 975-1000.

[9] Hosani, M. A., Anouti, F. A. (2014): A Preliminary Exploration of Heavy Metal Contamination within Aviccenia marina in the United Arab Emirates. - Journal of Environmental \& Analytical Toxicology 4: 232. DOI: 10.4172/2161-0525.1000232.

[10] Kim, R.-Y., Yoon, J.-K., Kim, T.-S., Yang, J. E., Owens, G., Kim. K.-R. (2015): Bioavailabilityof heavy metals in soils: definitions and practical implementation-a critical review. - Environmental Geochemical Health 37: 1041-1061.

[11] Lanno, R., Wells, J., Conder, J., Bradham, K., Basta, N. (2004): The bioavailability of chemicals in soil for earthworm. - Ecotoxicology and Environmental Safety 57(1): 39-47.

[12] Li, R., Chai, M., Qiu, G. Y. (2016): Distribution, fraction, and ecological assessment of heavy metals in sediment-plant system in mangrove forest, South China Sea. - PloS ONE 11(1). DOI: 10.1371/journal.pone.0147308.s.

[13] Liu, J., Wu, H., Feng, J., Li, Z., Lin, G. (2014): Heavy metal contamination and ecological risk assessments in the sediments and zoobenthos of selected mangrove ecosystems, South China. - CATENA 119: 136-142.

[14] Loring, D. H., Rantala, R. T. T. (1992): Manual for the geochemical analyses of marine sediments and suspended particulate matter. - Earth-Science Reviews 32: 235-283.

[15] MacDonald, D. D., Ingersoll, C. G., Berger, T. A. (2000): Development and evaluation of consensus-based sediment quality guidelines for freshwater ecosystems. - Archives of Environmental Contamination and Toxicology 39: 20-31.

[16] Macfarlane, G. R., Burchett, M. D. (2000): Cellular distribution of copper, lead and zinc in the grey mangrove, Avicennia marina (Forsk.) Vierh. - Aquatic Botany 68: 45-59.

[17] Nath, B., Birch, G., Chaudhuri, P. (2013): Trace metal biogeochemistry in mangrove ecosystems: a comparative assessment of acidified (by acid sulfate soils) and nonacidified sites. - Science of the Total Environment 463: 667-674.

[18] NaZli, M. F., Hashim, N. R. (2010): Heavy metal concentrations in an important mangrove species, Sonneratia Caseolaris, in Peninsular Malaysia. - Environnment Asia 3: 50-55.

[19] NOAA (1999): Sediment quality guidelines developed for the National Status and Trends Program. National Atmospheric Association. http://response.restoration.noaa.gov/book_shelf/121_sedi_qual_guide.pdf.

[20] Noriki, S. K., Nakanishi, T., Fukawa, M., Uematsu, T., Uchida, H., Tsunogai, S. (1980): Use of a teflon vessel for the decomposition followed by determination of chemical constituents of various marine samples. - Bulletin of the Faculty of Fisheries Hokkaido University 31: 345-465.

[21] Pendias, A. K., Pendias, H. (2001): Trace metals in soils and plants. - CRC Press, Boca Raton. 
[22] Pradit, S., Gao, Y., Faiboon, A., Baeyens, W., Leermakers, M. (2013): Application of DET (diffusive equilibrium in thin films) and DGT (diffusive gradients in thin films) techniques in the study of the mobility of sediment-bound metals in the outer section of Songkhla Lake, Southern Thailand. - Environmental Monitoring and Assessment 185: 4207-4220.

[23] Pradit, S., Sangmanee, W., Towatana, P., Shazili, N. A. M. (2016): Trace metals, grain size and organic matter in sediment from a coastal area in Pattani Bay, Thailand and setiuwetland, Malaysia. - Aquatic Ecosystem Health and Management 19: 345-354.

[24] Pradit, S., Wattayakorn, G., Angsupanich, S., Baeyens, W., Leermakers, M. (2010): Distribution of trace elements in sediments and biota of Songkhla Lake, Southern Thailand. - Water, Air, and Soil Pollution 206: 155-174.

[25] Rauret, G., López-Sánchez, J. F., Sahuquillo, A., Rubio, R., Davidson, C., Ure, A., Quevauviller, P. (1999): Improvement of the BCR three-step sequential extraction procedure prior to the certification of new sediment and soil reference materials. Journal of Environmental Monitoring 1: 57-61.

[26] Sarkar, S. K., Favas, P. J. C., Rakshit, D., Satpathy, K. K. (2014): Geochemical Speciation and Risk Assessment of Heavy Metals in Soils and Sediments. - In: Maria, C., Hernandez, S. (eds.) Environmental Risk Assessment of Soil Contamination. InTech Publishing, Rijeka.

[27] Sekomo, C. B., Nkuranga, E., Rousseau, D. P. L., Lens, P. N. L. (2011): Fate of heavy metals in and urban natural wetland: The Nyabugogo Swamp (Rwanda). - Water, Air, \& Soil Pollution 214: 321-333.

[28] Shazili, N. A. M., Mohamed, K. A. R., Husain, M. L., Asmawi, N., Salmah, A. (1999): Tracemetals in the surface sediments of the South China Sea, Area I: Gulf of Thailand and the East Coast of Peninsular Malaysia. - In: Proceedings of the First Technical Seminar on Marine Fishery Resources Survey in the South China Sea Area I Gulf of Thailand and East Coast of Peninsular Malaysia, pp. 73-85. Southeast Asian Fisheries Development Center, Samutprakan, Thailand.

[29] Sojisuporn, P. (2005): Sediment and shallower problems. In the master plan for Songkhla Lake basin development. - Water Resources 5: 167-191.

[30] Sompongchaiyakul, P., Sirinawin, W. (2007): Arsenic, Chromium and Mercury in surface sediment of Songkhla Lake system, Thailand. - Asian Journal of Water, Environment and Pollution 4(1): 17-24.

[31] Takac, P., Szabova, T., Benkova, M. (2009): Heavy metals and their bioavailability from soils in the long-term polluted central spis region of SR. - Plants Soil Environment 55(4): 167-172.

[32] Tokalioglu, S., Senol, K., Latif, E. (2000): Determination of heavy metals and their speciation in lake sediments by Flame Atomic Absorption Spectrometry after a four-stage sequential extraction procedure. - AnalyticaChimicaActa 413: 33-40.

[33] Toledo-Bruno, A. G. I., Aribal, L. G., Lustria, M. G. M., Marin, R. A. (2016): Phytoremediation potential of mangrove species at Pangasihan Mangrove forest reserve in Mandanao, Philippines. - Journal of Biodiversity and Environmental Sciences 9: 142149.

[34] USEPA (1989): Assessing Human Health Risks from Chemically Contaminated Fish and Shellfish. A Guidance Manual. - EPA503/8-89-002. USEPA, Washington, D. C.

[35] Zhong, X. L., S L Zhou, Q. Zhu, Zhao, Q. G. (2011). Fraction distribution and bioavailability of soil heavy metals in the Yangtze River Delta-A case study of Kushan City in Jiangsu Province, China. - Journal of Hazardous Materials 198: 13-21.

[36] Zhou, Y. W., Zhao, B., Peng, Y. S., Chen, G. Z. (2010): Influence of mangrove reforestation onheavy metal accumulation and speciation in intertidal sediments. - Marine Pollution Bulletin 60: 1319-1324. 